Article

\title{
Heating Energy and Peak-Power Demand in a Standard and Low Energy Building
}

\author{
Miimu Airaksinen ${ }^{1, *}$ and Mika Vuolle ${ }^{2}$ \\ 1 VTT Technical Research Centre of Finland, P.O. Box 1000, FI-02044 VTT, Finland \\ 2 Equa Simulation Finland Oy, Keskiyöntie 3, FI-02210 ESPOO, Finland; \\ E-Mail: mika.vuolle@equa.fi \\ * Author to whom correspondence should be addressed; E-Mail: miimu.airaksinen@vtt.fi; \\ Tel.: +358-40-770-4832; Fax: +358-20-722-7001.
}

Received: 7 November 2012; in revised form: 29 December 2012 / Accepted: 31 December 2012 / Published: 9 January 2013

\begin{abstract}
Building energy efficiency legislation has traditionally focused on space heating energy consumption. This has led to a decrease in energy consumption, especially in space heating. However, in the future when more renewable energy is used both on site and in energy systems, the peak energy demand becomes more important with respect to $\mathrm{CO}_{2}$ emissions and energy security. In this study it was found out the difference between space heating energy consumption was 55\%-62\% when a low energy and standard building were compared. However, the difference in peak energy demands was only $28 \%-34 \%$, showing the importance of paying attention to the peak demands as well.
\end{abstract}

Keywords: energy consumption; peak power demand; modeling; thermal mass

\section{Introduction}

While there is a general consensus that buildings' energy use and environmental impact must be reduced, there have been many discussions in the recent years as to the proper means and ways of achieving this. Buildings in Nature are consuming energy and it is obvious that the main target for buildings is to reduce the energy consumption and thus also reduce their environmental impact by way of reduced fossil fuel consumption.

In the European Union energy efficiency has been one of the main priority areas since it strongly affects sustainable energy resource use [1]. According to the International Energy Agency energy 
efficiency is considered to be the most cost-effective concrete action that governments can take in the short term to address climate change and to reduce energy consumption [2].

In Western countries buildings consume typically $40 \%$ of the energy [3-5]. In addition buildings are one of the most important sectors where there is significant technical and economic potential for improving energy efficiency. The residential sector alone currently accounts for $30 \%$ of all electricity consumed in developed countries, corresponding to $21 \%$ of energy-related $\mathrm{CO}_{2}$ emissions. According to the World Business Council for Sustainable Development energy use in buildings could be cut by $60 \%$ by 2050 if immediate actions to transform the building sector are taken [6].

There are several national and international initiatives and research projects to study and promote energy efficiency in buildings. Targets for improved energy use in buildings have also led to an increased interest in the use of thermal mass in buildings to see if that can offer energy efficiency and also thermal comfort advantages. However, in practice the lack of guidance about the detailed mechanisms that affect thermal mass and how it can be used in modern buildings has led to a tendency to equate high levels of physical mass with good passive thermal performance [7]. In reality, there are many other factors that need to be considered and increasing physical mass above certain thresholds does not necessarily improve thermal performance or energy efficiency. Many buildings today are structurally heavy but thermally lightweight. This is due to the use of finishes such as false floors and ceilings, gypsum wall linings, carpets, and other insulating finishes that effectively insulate the heavy structure from the internal environment. Often, it is more important to ensure that the design makes best use of available thermal mass than to add additional mass [8-10]

The European Parliament published the directive 2002/91/CE aimed at promoting energy efficiency in buildings. In April 2009, the European Parliament Industry Committee developed a report to reform the 2002 directive. This report proposes that by 31 December 2018 at the latest, EU Member States must ensure that all newly-constructed buildings will be close to Zero Energy Buildings. The close to zero energy building in EU is defined as "a building where, as a result of the very high level of energy efficiency of the building, the overall annual primary energy consumption is equal to or less than the energy production from Renewable Energy Sources on site" [11]. This concept does not establish any specific requirements on power consumption/generation patterns. The power exchange between grid and buildings will take place according to parameters like instantaneous home consumption needs and availability of renewable energy resources. Thus, even if a zero energy balance is achieved, the behavior with respect to the grid may not be optimal.

In a U.S. study [12] the total decrease in electrical demand due to energy efficiency and PV generation during the peak period was $46 \%$. Additionally when the indoor temperature was increased $2.2{ }^{\circ} \mathrm{C}$ the average demand during the peak period was further decreased by $69 \%$ of the demand from a standard home.

Renewable energy resources are often suggested to reduce the peak energy demand. However, that is very climate dependant. For example, in a study based on resource assessment carried out in India [13] it was found out that there exists a significant renewable energy potential to overcome the current peak loads in that country.

Thermally activated building systems with water circulating pipes gave good results in reducing peaks during cooling and heating periods in a study carried out in [14]. In that study reductions up to $50 \%$ of the cooling capacity for a chiller could be achieved in a temperate climate (The Netherlands). 
Demand side management is can be also used to reduce the peak load. However, this is always a question of behaviour, technology and economic interaction. A typical way of doing this kind of management is by using higher energy pricing during peak hours and the heat storing electric boilers or ice-storage air conditioners. Electrical boilers are typical ways to storage heat in direct electricity single family houses in Finland. In China there have been efforts to implement all the demand side management strategies to address the peak electricity demand [15]. In a study carried out in California, US, it was found out that residential sector can reduce peak demand clearly when critical peak pricing is applied [16].

In Australia the recent growth trend in commercial and residential peak electricity demand has led to the planning requirement for significant transmission capacity upgrades in New South Wales, Australia's most populous state. That has led to a substantial investment (US\$ 14.9 billion) to reinforce and strengthen the electricity network [17]. The Energy Supply Association of Australia estimated that $80 \%$ of the investment in grid upgrades was necessary to meet growing peak load demand [18].

A European study has showed that in February 2001 the peak load in Norway was 23,054 MW, which was close to the maximum capacity [19]. Also in Finland similar situations were reported in [19]. Thyholt [20] studied building code level and low energy houses with different heating sources and the effect on energy consumption, peak power demand and $\mathrm{CO}_{2}$ emissions. The study showed increased peak power demand due to electricity-based heating in low energy buildings. That study also showed higher $\mathrm{CO}_{2}$ emissions from low energy buildings with electricity-based heating in Norway.

The above mentioned facts highlight the importance not only of studying the energy consumption of buildings but also that the magnitude of the peak power is important. Therefore the aim of this study was to find out:

- $\quad$ how the thermal mass is affecting heating energy consumption in a building code level building and in a very low energy building;

- what is the difference in peak loads in heating and cooling both in passive and building code level building and is the thermal mass of the building affecting on peak load;

- how the peak load is depending on the model accuracy by using either single or multi zone models.

\section{Methods and Studied Building}

\subsection{Simulation Tool}

The studied building is modeled using the dynamic thermal simulation tools IDA Indoor Climate and Energy (IDA-ICE) [21]. Traditional monolithic simulation codes still dominate. IDA ICE has become the first widely spread thermal building performance simulator based on the new technology. IDA ICE is based on symbolic equations in a general modeling language and using a variable timestep differential-algebraic (DAE) solver.

IDA ICE is a well validated whole-year detailed and dynamic multi-zone simulation application for the study of thermal indoor climate as well as the energy consumption of an entire building. The physical models of IDA ICE reflect the latest research and best models available. The models are written in Neutral Model Format (NMF) or Modelica, which serves at the same time as a readable 
document and a computer code. Via translators, the models can be used in several modular simulation environments $[22,23]$.

\subsection{Studied Building}

The studied building is a one story single family house located in Helsinki, south Finland. The gross floor area of the one story building is $142 \mathrm{~m}^{2}$. The studied building is shown in Figure 1 and the simulation cases are listed in Table 1. Four cases were modeled: Constructions which fulfill the Finnish building code heat loss requirements (BC) and a very low energy level scenario, which was close to a passive house level. Thermal light and massive constructions were simulated as well. The heat capacity per floor area was $190 \mathrm{~kJ} / \mathrm{m}^{2} \mathrm{~K}$ for the light construction and $470 \mathrm{~kJ} / \mathrm{m}^{2} \mathrm{~K}$ for the massive construction. Air tightness, thermal bridges, glazing type of the windows and temperature ration of the ventilation heat recovery are changed, when the passive house level is introduced. All other input parameters are untouched. The main parameters are listed in Tables 1 and 2. The internal loads varied during daytime, being typical for residential buildings. The overall load is according to the 2012 Finnish building regulations, but the total internal loads are divided in different spaces according to typical living habits; e.g., bedrooms are occupied only during night time. The schedules are shown in the Table given at the end of the paper (Appendix).

Figure 1. Studied building.

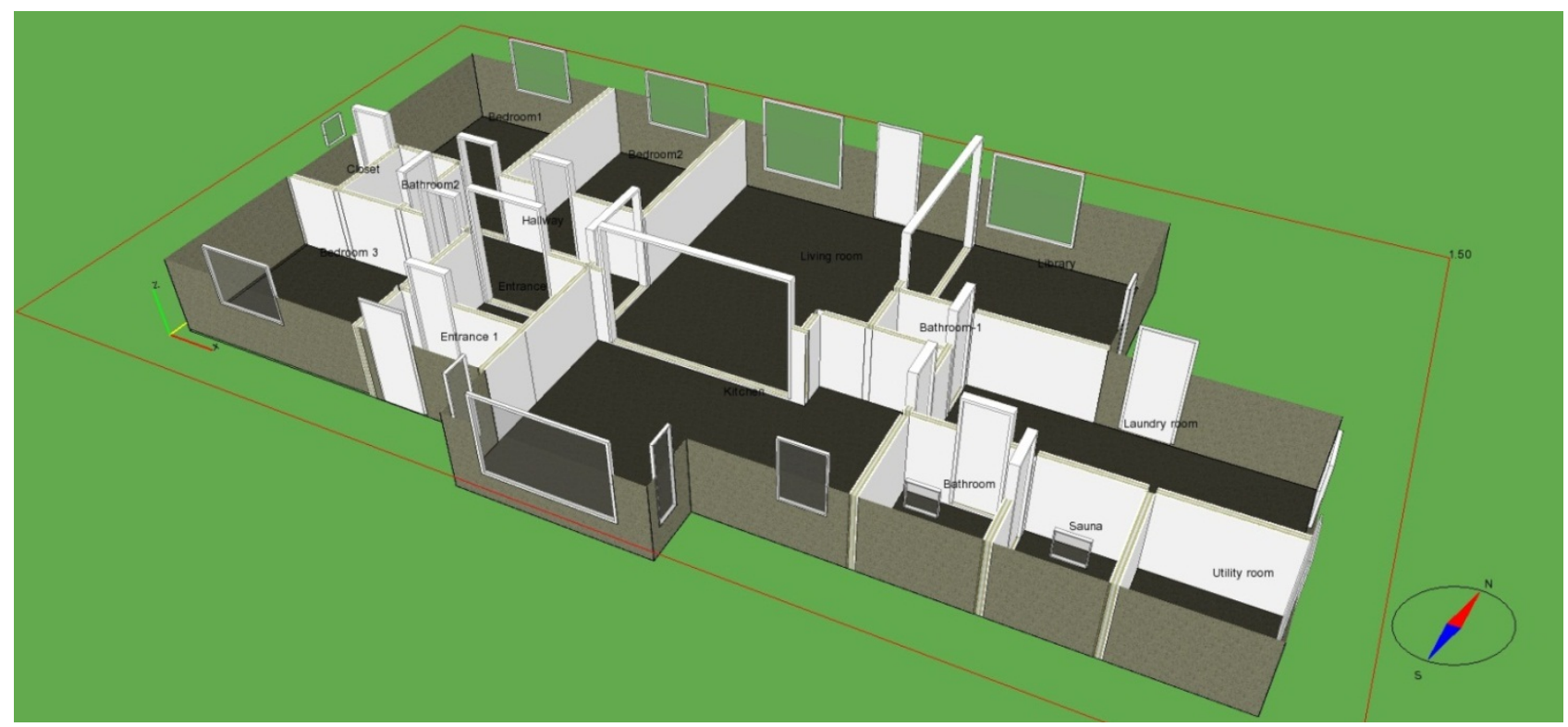


Table 1. Studied simulation cases.

\begin{tabular}{lcccc}
\hline Component or property & $\begin{array}{c}\text { Light } \\
\text { building code } \\
\text { (Light BC) }\end{array}$ & $\begin{array}{c}\text { Massive } \\
\text { building code } \\
\text { (Massive BC) }\end{array}$ & $\begin{array}{c}\text { Light } \\
\text { very low energy } \\
\text { (Light LowEn) }\end{array}$ & $\begin{array}{c}\text { Massive } \\
\text { very low energy } \\
\text { (Massive LowEn) }\end{array}$ \\
\hline Exterior wall $\left(\mathrm{W} / \mathrm{m}^{2} \mathrm{~K}\right)$ & 0.17 & 0.17 & 0.085 & 0.085 \\
Windows $\left(\mathrm{W} / \mathrm{m}^{2} \mathrm{~K}\right)$ & 1.0 & 1.0 & 0.6 & 0.6 \\
Window g-value $(-)$ & 0.68 & 0.68 & 0.30 & 0.30 \\
Ground floor $\left(\mathrm{W} / \mathrm{m}^{2} \mathrm{~K}\right)$ & 0.16 & 0.16 & 0.10 & 0.10 \\
Roof $\left(\mathrm{W} / \mathrm{m}^{2} \mathrm{~K}\right)$ & 0.09 & 0.09 & 0.06 & 0.06 \\
The heat capacity per & 190 & 470 & 190 & 470 \\
floor area $\left(\mathrm{kJ} / \mathrm{m}^{2} \mathrm{~K}\right)$ & 65 & 160 & 65 & 160 \\
Time constant $(\mathrm{h})$ & 45 & 45 & 80 & 80 \\
Temperature ration of & & & & $62 / 67$ \\
ventilation heat recovery $(\%)$ & $62 / 67$ & $62 / 67$ & $62 / 67$ & 0.6 \\
Supply/exhaust & 2.0 & 2.0 & 0.6 & \\
ventilation air flow $(\mathrm{dm} / \mathrm{s})$ & & & \\
$\mathrm{n}_{50}(1 / \mathrm{h})$ & & & & \\
\hline
\end{tabular}

Table 2. Internal gains.

\begin{tabular}{|c|c|c|c|c|c|c|c|}
\hline Zone & $\begin{array}{l}\text { Area } \\
\left(\mathbf{m}^{2}\right)\end{array}$ & $\begin{array}{l}\text { Supply air } \\
\left(\mathbf{L} / \mathbf{s ~ m}^{2}\right)\end{array}$ & $\begin{array}{c}\text { Exhaust air } \\
\left(\mathrm{L} / \mathbf{s ~ m}^{2}\right)\end{array}$ & $\begin{array}{c}\text { Occupants } \\
\left(\text { persons } / \mathbf{m}^{2}\right)\end{array}$ & $\begin{array}{c}\text { Lights } \\
\left(\mathbf{W} / \mathbf{m}^{2}\right)\end{array}$ & $\begin{array}{c}\text { Equipment } \\
\left(\mathbf{W} / \mathbf{m}^{2}\right)\end{array}$ & $\begin{array}{c}\text { External } \\
\text { window } \\
\operatorname{area}\left(\mathrm{m}^{2}\right)\end{array}$ \\
\hline Bathroom & 3.3 & 0 & 4.484 & 0.3 & 3.0 & 0 & 0.25 \\
\hline Bathroom 1 & 1.2 & 0 & 8.482 & 0.8 & 5.1 & 0 & 0 \\
\hline Bathroom 2 & 2.2 & 0 & 4.64 & 0.5 & 2.8 & 0 & 0 \\
\hline Bedroom 3 & 12.0 & 1.003 & 0 & 0.1 & 3.9 & 0.75 & 1.68 \\
\hline Bedroom 1 & 13.0 & 0.922 & 0 & 0.2 & 5.4 & 0.69 & 1.68 \\
\hline Bedroom 2 & 10.9 & 1.102 & 0 & 0.1 & 4.6 & 0.83 & 1.68 \\
\hline Closet & 1.7 & 0 & 1.738 & 0 & 0 & 0 & 0.25 \\
\hline Entrance & 4.1 & 0 & 0 & 0 & 2.4 & 0 & 0 \\
\hline Entrance 1 & 2.5 & 0 & 0 & 0 & 2.4 & 0 & 0 \\
\hline Hallway & 6.5 & 0 & 0 & 0.2 & 2.3 & 0 & 0 \\
\hline Kitchen & 23.0 & 0 & 0.348 & 0.04 & 5.2 & 14.13 & 6.4 \\
\hline Laundry & 15.2 & 0 & 0.989 & 0.1 & 3.0 & 4.94 & 0.96 \\
\hline Library & 13.6 & 0.736 & 0 & 0.04 & 2.6 & 0 & 3.52 \\
\hline Living $\mathrm{R}$ & 26.2 & 0.382 & 0 & 0.1 & 6.9 & 4.58 & 2.72 \\
\hline Sauna & 2.9 & 2.064 & 2.064 & 0.3 & 8.6 & 0 & 0.25 \\
\hline Utility & 3.8 & 0 & 0 & 0 & 0 & 13.17 & 0 \\
\hline
\end{tabular}

\subsection{Building Model}

The simulation model was created from a building information model (BIM) by using the IFC file. Each room is modeled as a space of its own. All spaces have separate internals loads (occupancy, light and appliances) with schedules. We have tried to achieve realistic variable loads of the rooms according to the room type and at the same time to get the annual/monthly loads in energy values, which are defined in the national building code monthly calculation method. 
Supply and exhaust air flows are set space by space according to the ventilation design. Doors are opened between most spaces, thus bidirectional air flows occur when the pressure levels make it possible and due to that temperature and air quality differences between spaces are reduced. The doors to the toilets, the entrance, the bathroom and the closet are closed. The closed doors introduced a leak between spaces, thus the transfer air is taken account.

Air tightness is given as a $\mathrm{n}_{50}$-parameter and actual in- and exfiltration is simulated with the fully air flow network option of IDA-ICE. Typical pressure coefficients for single family house are introduced.

Total air flows and air tightness are shown at Table 1. Two additional models are also created without any internal loads. One with space by space with designed air flows and another as a single zone model with the same air flows and internal walls are defined as thermal mass. The models are created to study space heating power needs with the different zoning approaches.

\section{Results}

The highest space heating energy consumption was with the buildings build according to the Finnish building code. There were not big differences if the structures had more thermal mass or if they were light weight. It should be noted the light weight construction also had concrete base floor since the floor construction was based on ground soil. Actually the difference between a massive building with a lower window g-value had a higher impact on energy consumption than the thermal mass of the structures, Table 4 . The differences were rather small, only between 1.5 and $2.5 \mathrm{kWh} / \mathrm{m}^{2}$. A clear difference could be seen when the building code level was substituted with very low energy building structures (passive house). The space heating consumption was roughly half as much as the space heating consumption in the building code level. In very low energy buildings the difference between massive and light weight structure was smaller compared to building code level differences, but the lower window g-value increased the space heating consumption clearly more. The increase was between 5.3 and $5.5 \mathrm{kWh} / \mathrm{m}^{2}$.

When the highest peak power demands for space heating were considered, the difference between building code level and very low energy building is between 8.6 and $11.8 \mathrm{~W} / \mathrm{m}^{2}$, being $28 \%-35 \%$ smaller compared to the building code level power demand. This is clearly less lower than the space heating energy consumption, Table 3.

Table 3. Space heating energy consumption in simulated cases $\left(\mathrm{kWh} / \mathrm{m}^{2}\right)$.

\begin{tabular}{lcc}
\hline Cases & $\begin{array}{c}\text { Space heating energy } \\
\text { consumption }\left(\mathbf{k W h} / \mathbf{m}^{\mathbf{2}}\right)\end{array}$ & $\begin{array}{c}\text { Space heating peak } \\
\text { power demand }\left(\mathbf{W} / \mathbf{m}^{2}\right)\end{array}$ \\
\hline Massive building code & 70.5 & 32.1 \\
Massive building code with sun shading & 73.1 & 30.3 \\
Light building code & 72.0 & 34.2 \\
Light building code with sun shading & 74.4 & 32.4 \\
Massive very low energy & 27.1 & 21.5 \\
Massive very low energy with sun shading & 32.5 & 21.7 \\
Light very low energy & 27.9 & 22.4 \\
Light very low energy with sun shading & 33.2 & 22.6 \\
\hline
\end{tabular}


When same building was simulated in different climates the reduction in a very low energy building compared to standard building in both energy consumption and peak power demand was higher compared to the Finnish cold climate, Table 4. In a Berlin (Germany) climate, the reduction in space heating energy consumption was $71 \%$ and the peak power demand reduction was $53 \%$, respectively. In the Madrid climate in Spain the reduction in space heating energy consumption was $90 \%$ and $81 \%$ in peak power. Obviously the energy and peak demands were also clearly lower in southern climates.

Table 4. Space heating energy consumption in different climates $\left(\mathrm{kWh} / \mathrm{m}^{2}\right)$.

\begin{tabular}{lcc}
\hline Cases & $\begin{array}{c}\text { Space heating energy } \\
\text { consumption }\left(\mathbf{k W h} / \mathbf{m}^{\mathbf{2}}\right)\end{array}$ & $\begin{array}{c}\text { Space heating peak } \\
\text { power demand }\left(\mathbf{W} / \mathbf{m}^{\mathbf{2}}\right)\end{array}$ \\
\hline Massive building code Helsinki (Finland) & 70.5 & 32.1 \\
Massive very low energy Helsinki (Finland) & 27.1 & 21.5 \\
Massive building code Berlin (Germany) & 43.2 & 21.2 \\
Massive very low energy Berlin (Germany) & 12.6 & 9.9 \\
Massive building code Madrid (Spain) & 12.1 & 14.6 \\
Massive very low energy Madrid (Spain) & 1.2 & 2.7 \\
\hline
\end{tabular}

In the following simulations only Finnish climate is considered. In addition to energy consumption, obviously the power demand generally is higher with building code level building compared to very low energy building (Figure 2). The heating period is clearly shorter with very low energy buildings (Figures 2 and 3). The length of heating period is 8.9 months for building code light structured building and 8.8 months for a similar building with higher thermal mass. The length of very low energy building is 7.3 months for a building with light thermal mass and 7.0 for one with high thermal mass. The percentage of peak heating hours of the total heating hours is both in building code level and very low energy level roughly the same, Table 5.

Figure 2. Power demand for space heating $\left(\mathrm{W} / \mathrm{m}^{2}\right)$.

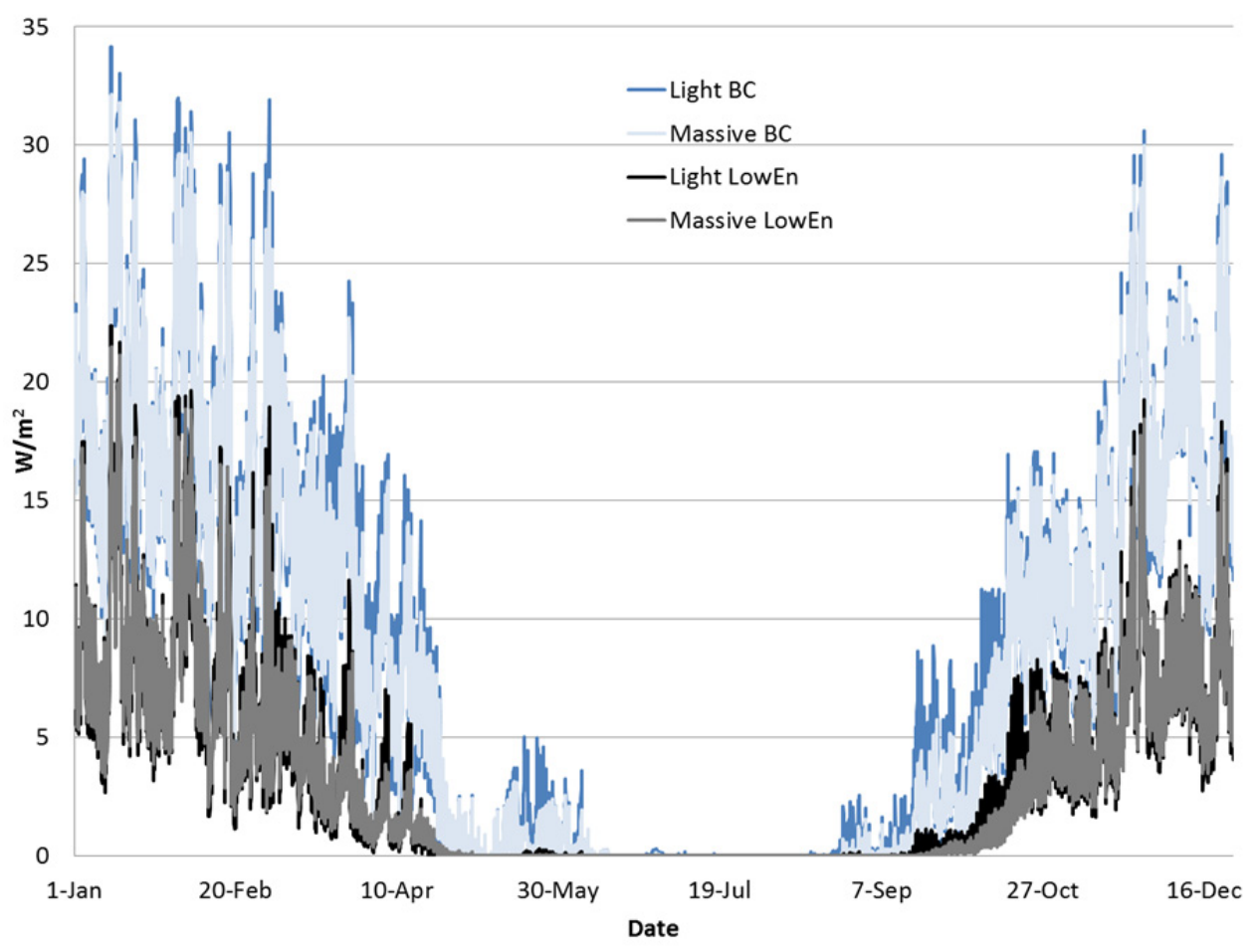


Figure 3. Duration curves of space heating power consumption $\left(\mathrm{W} / \mathrm{m}^{2}\right)$.

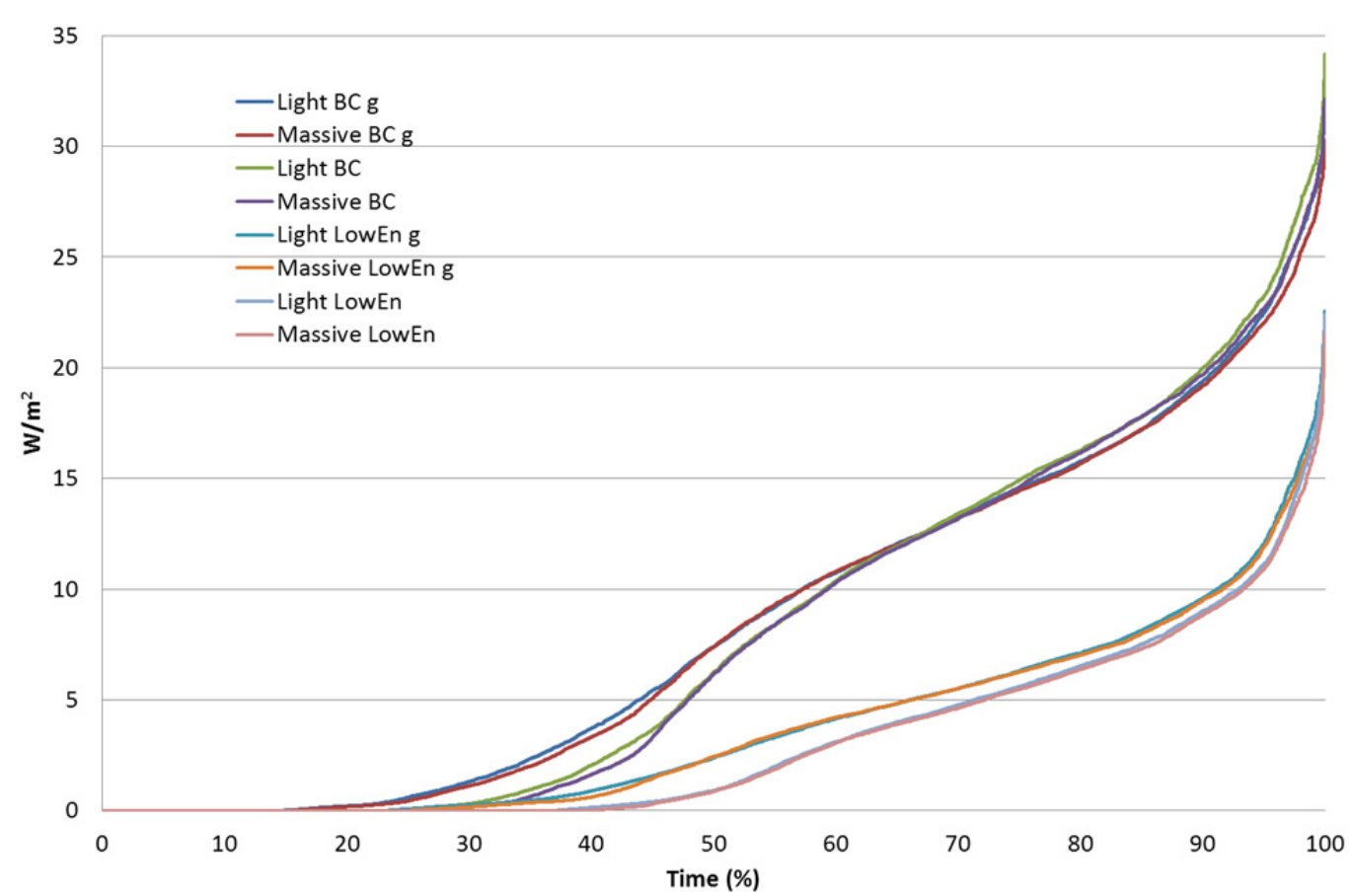

Table 5. Total heating hours of the year, peak heating hours and the percentage of peak heating hours compared to total heating hours. The peak heating hours are the hours in which the power demand in higher than $20 \mathrm{~W} / \mathrm{m}^{2}$ in building code level building (BC) and the limit is $10 \mathrm{~W} / \mathrm{m}^{2}$ for the low energy building (LowEn).

\begin{tabular}{lcccc}
\hline Hours and percentages & Light BC & Massive BC & Light LowEn & Massive LowEn \\
\hline Heating hours per year (h) & 6498 & 6419 & 5341 & 5091 \\
Peak heating hours (h) & 875 & 822 & 620 & 587 \\
Percentage of peak heating hours (\%) & $13 \%$ & $13 \%$ & $12 \%$ & $12 \%$ \\
\hline
\end{tabular}

The model of the building clearly affects the results. To study the effect of model internal loads were removed in order to see the behavior of the peak power demand without the user influence. In the multizone model all internal doors were open as they typically are in normal living conditions. The exception was bathrooms, sauna, utility room and laundry, whose doors were closed as they typically are in normal living conditions. Sunshine obviously affected the behavior of the peak demand. If the apartment of the building is modeled as a single zone the heating peak loads are lower and the heating hours are also clearly lower. The maximum difference in peak loads is $3.4 \mathrm{~W} / \mathrm{m}^{2}$. Even though the peak load as a such is not a high number, but compared that to the actual load at the moment $\left(6.1 \mathrm{~W} / \mathrm{m}^{2}\right.$ for the single zone and $9.5 \mathrm{~W} / \mathrm{m}^{2}$ for the multizone model) the change in percentage is high $(55 \%)$. This clearly highlights the importance of multizone modeling when power demand is considered. In addition due to the single zone modeling assumptions the zone specific errors can become high.

When building level peak loads are considered the difference is between single zone and multizone models are clear, as could be seen from Figure 4. However, when the peak load inside the building zones were studied huge differences could be found (Figure 5). 
Figure 4. Power demand for space heating $(\mathrm{W} / \mathrm{m} 2)$ in individual rooms for a massive low energy building.

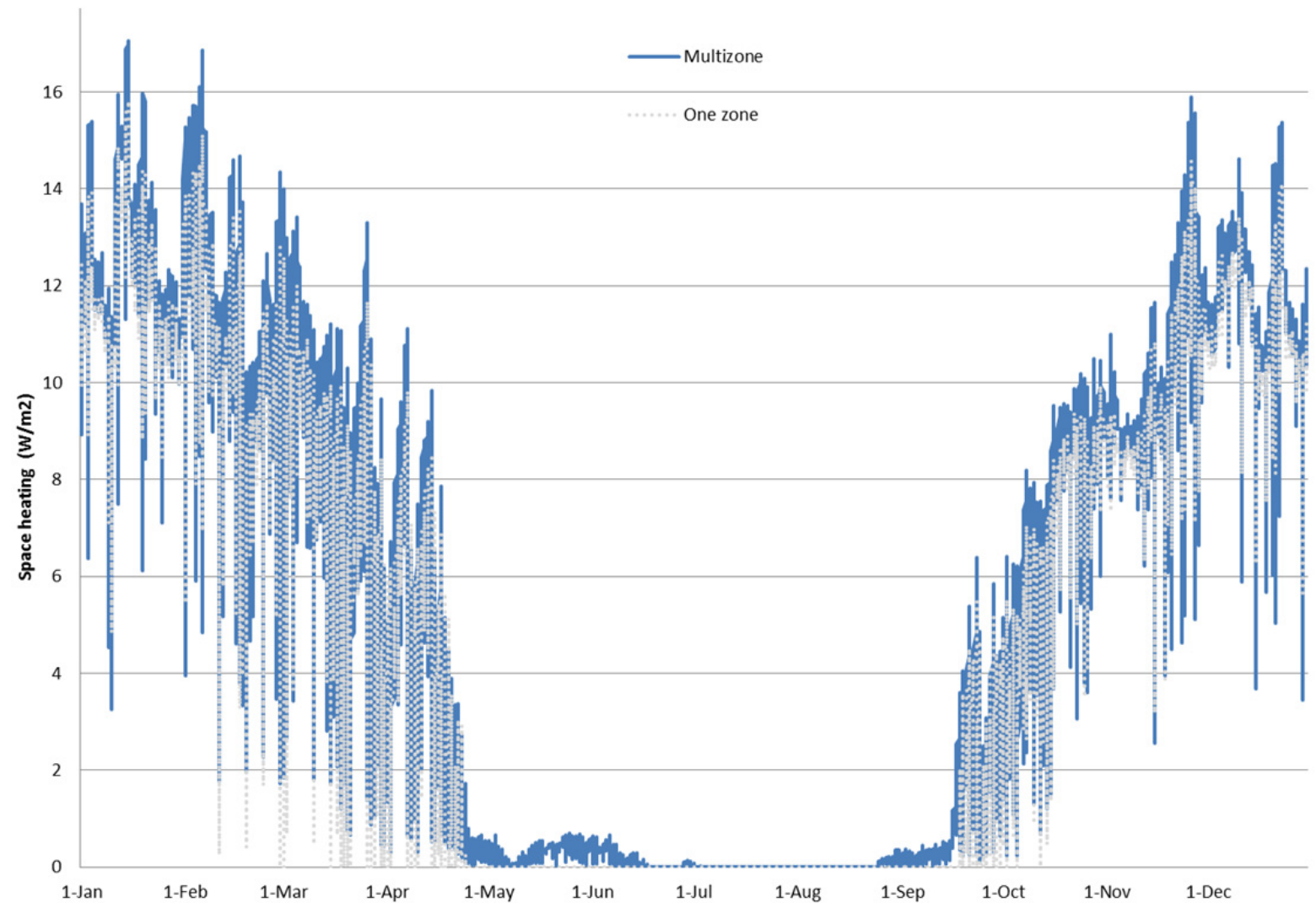

Figure 5. Power demand for space heating $\left(\mathrm{W} / \mathrm{m}^{2}\right)$ in each zone inside the building.

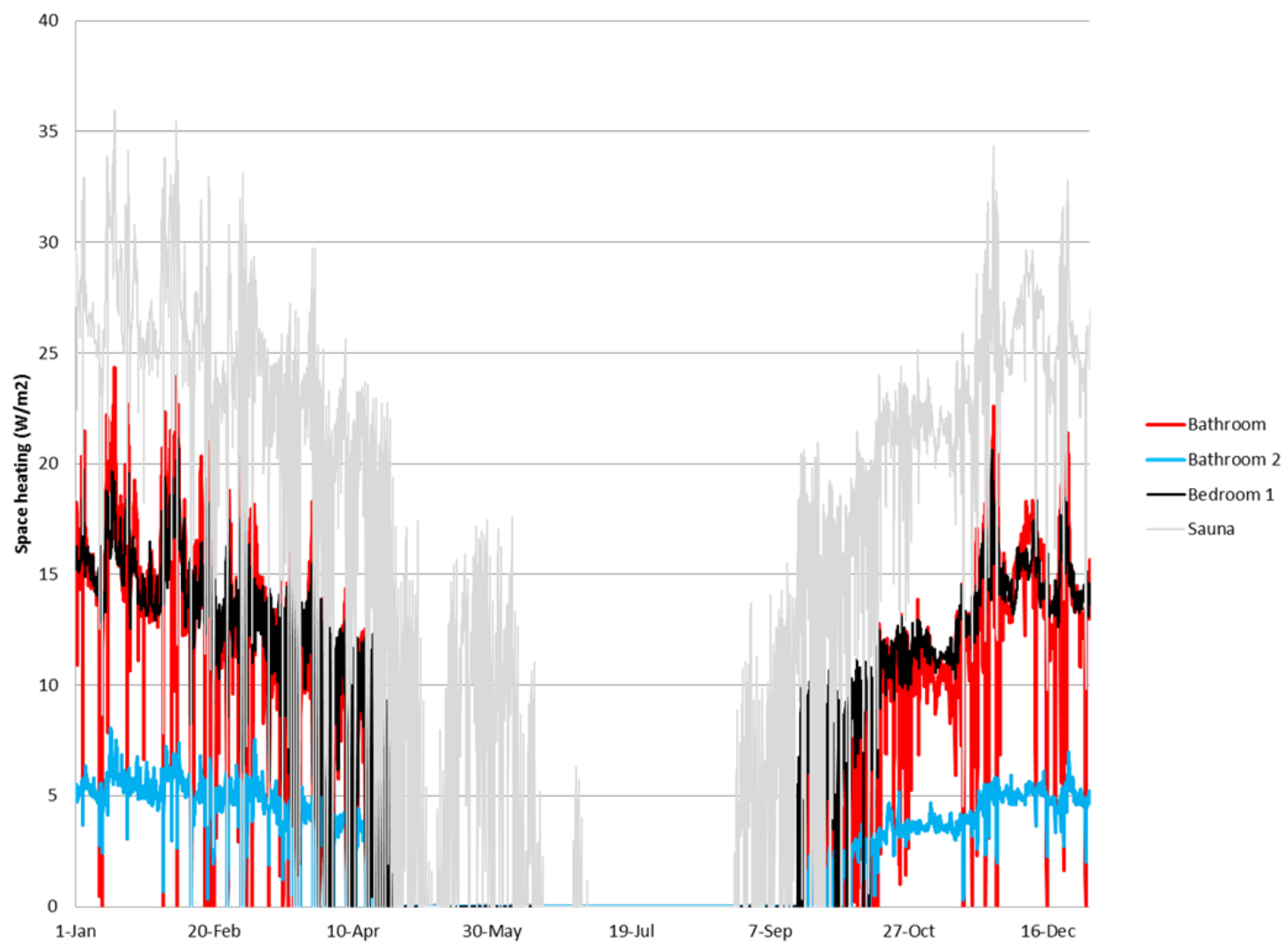


The absolute power demand is obviously same as in Figure 4, but since rooms are located on different facades, the specific space heating power demand has big differences. Sauna had highest specific power demand due to the fact that it has relatively large area of exterior walls and also because it is connected to bathroom which only has exhaust air, which is a typical way to design it. Bathroom 1 and 2 had the lowest specific heat power demand since they were located inside the building. This shows clearly that each room should have individual control units in order to maintain comfortable indoor conditions in each room.

\section{Discussion}

Energy efficient buildings generally have lower peak loads compared to standard buildings, but the difference in much higher in energy consumption than in peak loads, e.g., [14]. In addition specific technical and management factors within each building significantly affect its peak load in real use of the building. In a Norwegian study [20] it was found out that when using electricity for heating purposes in the low-energy cases, the annual emissions of $\mathrm{CO}_{2}$ related to heating purposes were generally higher than for the reference case. The reference building used district heating and low energy building electricity as heating energy sources in that study. Putting that to a longer term perspective, new residential building stock corresponding to the low-energy buildings with electrical heating, will lead to an increased peak power demand of about 1000-1200 MW after 20 years in Norway. This increased peak power demand corresponds to about 5\% of today's peak power capacity in the electricity supply in Norway [20].

For cooling loads the study by [24] showed that the more efficient buildings have a "peakier" load profile, although the absolute peak loads were clearly lower compared to standard buildings. This "peakiness" may be a result of the design of the energy efficient buildings, which utilise passive measures to maintain comfort, but as the temperature rises significantly, proportionally higher air-conditioning loads are needed to meet the increased cooling requirements.

The mechanisms behind thermal mass are complex and benefits may not always be as assumed by a simple assessment [9]. According to [9] thermal mass shows small benefits in cooling but might increase heating. In this study the thermal mass showed a slight decrease in heating. This study was carried out a sub-Artic climate whereas the study of [9] used a central European climate. Similar results were found also in [25] where five different simulations tools were used.

In a study by [26] it was found out that if the studied building is simple enough heating energy calculations can be done by a monthly method or with a single zone or multi-zone models with similar accuracy. However, in the same study it was shown that when the building model was more complex and different internal gains were used the results were clearly different showing the importance of accurate modeling in complex cases.

\section{Conclusions}

This study has compared a building built according to Finnish building code level and a very low energy building (close to passive house level). Obviously the highest space heating energy consumption was with the buildings built according to Finnish building code. There were no big differences if the structures had more thermal mass or if they were thermally light weight. It should be 
noted the light weight construction also had concrete base floor since the floor construction was based on ground soil. Actually the difference between massive buildings with a lower window g-value had a higher impact on energy consumption than the thermal mass of the structures. The differences were rather small, only between 1.5 and $2.5 \mathrm{kWh} / \mathrm{m}^{2}$. A clear difference in energy consumption could be seen when the building code level was substituted with very low energy building structures (passive house). The space heating consumption was roughly half as much as the space heating consumption in the building code level. In very low energy buildings the difference between massive and light weight structure was smaller compared to building code level differences, but the lower window g-value clearly increased the space heating consumption more, between 5.3 and $5.5 \mathrm{kWh} / \mathrm{m}^{2}$.

This study confirms that energy efficient buildings do have reduced peaks, but the reduction is not as significant as the reductions in energy use achieved, especially in cold climates. In moderate and warm climates the reductions in both energy and power demands were higher in percentage but also the absolute heating demand is clearly lower. When the highest peak power demands for space heating was considered, the difference between building code level and very low energy building was between 8.6 and $11.8 \mathrm{~W} / \mathrm{m}^{2}$, being $28 \%-34 \%$ smaller compared to the building code level power demand. When that is compared to energy consumption difference, where the building code and very low energy building differences were between $55 \%$ and $62 \%$, thus, it can be clearly noted that even though there is a huge difference in energy consumption levels, the difference in peak power demands is clearly lower.

When building level peak loads were considered the difference between single zone and multizone models were clear. However, when the peak load inside the building zones (rooms) were studied huge differences could be found due to zone location and ventilation. That clearly shows that each room should have individual control units in order to maintain comfortable indoor conditions in each room.

\section{References}

1. De Alegría Mancisidor, I.M.; de Basurto Uraga, P.Z.; de Alegría Mancisidor, I.M.; de Arbulo López, P.R. European Union's renewable energy sources and energy efficiency policy review: The Spanish perspective. Renew. Sustain. Energy Rev. 2009, 13, 100-114.

2. IEA. Energy Technology Perspectives 2012, Pathways to a Clean Energy System; IEA: Paris, France, 2012; pp. 1-690.

3. EU Energy and Transport in Figures, Statistical Pocket Book 2007/2008; European Communities: Brussels, Belgium, 2008.

4. Swedish Energy Ageancy (SEA). Energy in Sweden, Facts and Figures; SEA: Eskilstuna, Sweden, 2002.

5. Intergovernmental Panel on Climate Change (IPCC). Climate Change 2001: Mitigation; Third Assessment Report; Working Group III, IPCC: New York, NY, USA, 2001.

6. WBCSD. Changing Pace, Public Policy Options to Scale and Accelerate, Business Action Towards Vision 2050; World Business Council for Sustainable Development: Geneva, Switzerland, 2012. Available online: http://www.wbcsd.org/Pages/EDocument/EDocumentDetails.aspx?ID= $14622 \&$ NoSearchContextKey $=$ true (accessed on 31 October 2012). 
7. Amato, A.; Kendrick, C.; Ogden, R.; Plank, R. Practical ceiling solutions for thermally efficient steel frame buildings. In Proceedings of Chartered Institute of Building Services Engineers (CIBSE) National Conference, Bournemouth, UK, 18-20 October 1998.

8. Barnard, N. Modeling the Performance of Thermal Mass; BRE Information Paper IP6/01; Building Research Establishment: Berkshire, UK, 2001.

9. Gorgolewski, M.T.; Liao, Z.; Clarida, R. Thermal Mass in Office Buildings, Research in Building Physics and Building Engineering; Fazio, P. Ge, H., Rao, J., Desmarais, G., Eds.; Taylor \& Francis Group: London, UK, 2006; ISBN 0-415-41675-2.

10. Becker, R.; Paciuk, M. Inter-related effects of cooling strategies and building features on energy performance of office buildings. Energy Build. 2002, 34, 25-31.

11. European Directive Proposal; COM (2008)0780 e C6-0413-2008 e 2008/0223 (COD); The energy performance of buildings (recast version), April 2009.

12. Sadineni, S.; Boehm, R. Measurements and simulations for peak electrical load reduction in cooling dominated climate. Energy 2012, 37, 689-697.

13. Dudhani, S.; Sinha, A.K.; Inamdar, S.S. Renewable energy sources for peak load demand management in India. Int. J. Electr. Power Energy Syst. 2006, 28, 396-400.

14. Rijksen, D.O.; Wisse, C.J.; van Schijndel, A.W.M. Reducing peak requirements for cooling by using thermally activated building systems. Energy Build. 2010, 42, 298-304.

15. Wang, J.; Bloyd, C.N.; Hu, Z.; Tan, Z. Demand response in China. Energy 2010, 35, 1592-1597.

16. Herter, K.; McAuliffe, P.; Rosenfeld, A. An exploratory analysis of California residential customer response to critical peak pricing of electricity. Energy 2007, 32, 25-34.

17. Australian Energy Regulator (AER). TransGrid Transmission Determination; Final Report, 2009-10 to 2013-14. Available online: http://www.aer.gov.au/node/3333 (accesses on 31 October 2012).

18. Smith, M.; Hargroves, K.; Stasinopoulos, P.; Stephens, R.; Desha, C.; Hargroves, S. Energy Transformed: Sustainable Energy Solutions for Climate Change Mitigation; The Natural Edge Project (TNEP), Commonwealth Scientific and Industrial Research Organisation (CSIRO): Clayton, Australia; Griffith University: Nathan, Australia, 2007.

19. Efflocom. Phase $1+2$ Customer segmentation, EU project: "Energy EFFiciency and LOad curve impacts of COMmercial development in competitive markets", 2001. Available online: http://www.sintef.no/Projectweb/Efflocom/DisseminationDocumentation/ (accessed on 31 December 2012).

20. Thyholt, M.; Hestnes, A.G. Heat supply to low-energy buildings in district heating areas, Analyses of $\mathrm{CO}_{2}$ emissions and electricity supply security. Energy Build. 2008, 40, 131-139.

21. IDA Simulation Environment. Available online: http://www.equa-solutions.co.uk/ (accessed on 31 October 2012).

22. Sahlin, P.; Eriksson, L.; Grozman, P.; Johnsson, H.; Shapovalov, A.; Vuolle, M. Whole-building simulation with symbolic DAE equations and general purpose solvers. Build. Environ. 2012, 39, 949-958.

23. Sahlin, P.; Eriksson, L.; Grozman, P.; Johnsson, H.; Shapovalov, A.; Vuolle, M. Will Equation-Based Building Simulation Make it? Experiences from the Introduction of IDA Indoor Climate and Energy, In Proceedings of 8th International (IBPSA) International Building Performance Simulation Association Conference, Eindhoven, The Netherlands, 11-14 August 2003. 
24. Steinfeld, J.; Bruce, A.; Watt, M. Peak load characteristics of Sydney office buildings and policy recommendations for peak load reduction. Energy Build. 2011, 43, 2179-2187.

25. Kalema, T.; Pylsy, P.; Hagengran, P.; Johannesson, G.; Airaksinen, M.; Dokka, T.H.; Öberg, M.; Pöysti, M.; Rapp, K.; Keski-Opas, J. Nordic Thermal Mass-Effect on Energy and Indoor Climate; Tampere University of Technology: Tampere, Finland, 2006; Report 184, p. 105.

26. Kalema, T.; Johannesson, G.; Pylsy, P.; Hagengran, P. Accuracy of energy analysis of buildings: A comparison of a monthly energy balance method and simulation methods in calculating the energy consumption and the effect of thermal mass. J. Build. Phys. 2008, 32, 101-130.

\section{Appendix}

Table A1. Schedules and weight factors for internal loads, time corresponds when the loads according to Table 2 are on. Weight factor 1 corresponds that all internal load is present, weight factor 0.5 corresponds that $50 \%$ of the internal load shown in Table 2 is on. The clock hours are given in [], e.g., 0.5 [6:30-8:00] corresponds to a $50 \%$ internal load between 6:30-8:00 o'clock.

\begin{tabular}{|c|c|c|c|}
\hline Name & Occupants & Lights & Equipment \\
\hline Bathrooms & $\begin{array}{l}\text { - Weekdays: } \\
1 \text { [7:00-7:30, 16:00-16:30, } \\
\text { 18:00-18:15, 19:45-20:15, } \\
\text { 22:00-22:15], } 0 \text { otherwise } \\
\text { - Saturday: } \\
1 \text { [8:45-9:15, 11:45-12:15, } \\
\text { 15:00-15:15, 18:00-18:15, } \\
\text { 19:00-20:00, 22:00-22:15], } \\
0 \text { otherwise } \\
\text { - Sunday and holidays: } \\
\text { 1 [8:45-9:15, 11:45-12:15, } \\
\text { 15:00-15:15, 18:00-18:15, } \\
\text { 19:00-20:00, 22:00-22:15], } \\
0 \text { otherwise }\end{array}$ & $\begin{array}{l}\text { - Weekdays: } \\
1 \text { [7:00-7:30, 16:00-16:30, } \\
\text { 18:00-18:15, 19:45-20:15, } \\
\text { 22:00-22:15], } 0 \text { otherwise } \\
\text { - Saturday: } \\
1 \text { [8:45-9:15, 11:45-12:15, } \\
\text { 15:00-15:15, 18:00-18:15, } \\
\text { 19:00-20:00, 22:00-22:15], } \\
0 \text { otherwise } \\
\text { - Sunday and holidays } 1: \\
1 \text { [8:45-9:15, 11:45-12:15, } \\
\text { 15:00-15:15, 18:00-18:15, } \\
\text { 19:00-20:00, 22:00-22:15], } \\
0 \text { otherwise }\end{array}$ & - \\
\hline Bedrooms & $\begin{array}{l}\text { - Weekdays: } \\
0.5 \text { [6:00-8:00, 22:00-23:00], } \\
0 \text { [8:00-22:00], } 1 \text { otherwise } \\
\text { - Saturday: } \\
1 \text { [0:00-8:00], } 0.5 \text { [8:00-10:00, } \\
\text { 23:00-24:00], } 0 \text { otherwise } \\
\text { - Sunday and holidays: } \\
1 \text { [0:00-8:00], } 0.5 \text { [8:00-10:00, } \\
\text { 23:00-24:00], } 0 \text { otherwise }\end{array}$ & $\begin{array}{l}\text { - Weekdays: } \\
1 \text { [6:00-8:00, 22:00-23:00], } \\
0 \text { otherwise } \\
\text { - Saturday: } \\
1 \text { [8:00-10:00, 23:00-24:00], } \\
0 \text { otherwise } \\
\text { - Sunday and holidays: } \\
1 \text { [8:00-10:00, 23:00-24:00], } \\
0 \text { otherwise }\end{array}$ & $\begin{array}{l}\text { - Weekdays: } 1 \\
\text { - Saturday: } 1 \\
\text { - Sunday and holidays: } 1\end{array}$ \\
\hline Closet & - & - & - \\
\hline
\end{tabular}


Table A1. Cont.

\begin{tabular}{|c|c|c|c|}
\hline Name & Occupants & Lights & Equipment \\
\hline Entrances & - & $\begin{array}{l}\text { - Weekdays: } \\
\text { 1 [7:00-7:30, 16:00-16:30, } \\
\text { 18:00-18:15, 19:45-20:15, } \\
\text { 22:00-22:15], 0 otherwise } \\
\text { • Saturday: } \\
\text { 1 [8:45-9:15, 11:45-12:15, } \\
\text { 15:00-15:15, 18:00-18:15, } \\
\text { 19:00-20:00, 22:00-22:15], } \\
0 \text { otherwise } \\
\text { - Sunday and holidays: } \\
\text { 1 [8:45-9:15, 11:45-12:15, } \\
\text { 15:00-15:15, 18:00-18:15, } \\
\text { 19:00-20:00, 22:00-22:15], } \\
0 \text { otherwise }\end{array}$ & - \\
\hline Hallway & $\begin{array}{l}\text { - Weekdays: } \\
1 \text { [7:00-7:30, 16:00-16:30, } \\
\text { 18:00-18:15, 19:45-20:15, } \\
\text { 22:00-22:15], } 0 \text { otherwise } \\
\text { - Saturday: } \\
\text { 1 [8:45-9:15, 11:45-12:15, } \\
\text { 15:00-15:15, 18:00-18:15, } \\
\text { 19:00-20:00, 22:00-22:15], } \\
0 \text { otherwise } \\
\text { - Sunday and holidays: } \\
1 \text { [8:45-9:15, 11:45-12:15, } \\
15: 00-15: 15,18: 00-18: 15, \\
\text { 19:00-20:00, 22:00-22:15], } \\
0 \text { otherwise }\end{array}$ & Same as living room & \\
\hline Kitchen & Same as living room & Same as living room & $\begin{array}{l}\text { - Weekdays: } \\
0.5 \text { [6:30-8:00, 15:00-16:00], } \\
1.0 \text { [16:00-18:00], } \\
0.25 \text { otherwise } \\
\text { - Saturday: } \\
0.5 \text { [8:00-10:00, 18:00-20:00], } \\
0.75 \text { [12:00-14:00], } \\
0.25 \text { otherwise } \\
\text { - Sunday and holidays: } \\
0.5 \text { [8:00-10:00, 18:00-20:00], } \\
0.75 \text { [12:00-14:00], } \\
0.25 \text { otherwise }\end{array}$ \\
\hline
\end{tabular}


Table A1. Cont.

\begin{tabular}{|c|c|c|c|}
\hline Name & Occupants & Lights & Equipment \\
\hline $\begin{array}{l}\text { Laundry } \\
\text { room }\end{array}$ & $\begin{array}{l}\bullet \text { Weekdays: } \\
\text { 1 [7:00-7:30, 16:00-16:30, } \\
\text { 18:00-18:15, 19:45-20:15, } \\
\text { 22:00-22:15], } 0 \text { otherwise } \\
\text { • Saturday: } \\
\text { 1 [8:45-9:15, 11:45-12:15, } \\
\text { 15:00-15:15, 18:00-18:15, } \\
\text { 19:00-20:00, 22:00-22:15], } \\
0 \text { otherwise } \\
\text { - Sunday and holidays: } \\
\text { 1 [8:45-9:15, 11:45-12:15, } \\
\text { 15:00-15:15, 18:00-18:15, } \\
\text { 19:00-20:00, 22:00-22:15], } \\
0 \text { otherwise }\end{array}$ & $\begin{array}{l}- \text { Weekdays: } \\
1 \text { [7:00-7:30, 16:00-16:30, } \\
\text { 18:00-18:15, 19:45-20:15, } \\
\text { 22:00-22:15], } 0 \text { otherwise } \\
\text { - Saturday: } \\
\text { 1 [8:45-9:15, 11:45-12:15, } \\
\text { 15:00-15:15, 18:00-18:15, } \\
\text { 19:00-20:00, 22:00-22:15], } \\
0 \text { otherwise } \\
\text { - Sunday and holidays: } \\
\text { 1 [8:45-9:15, 11:45-12:15, } \\
\text { 15:00-15:15, 18:00-18:15, } \\
\text { 19:00-20:00, 22:00-22:15], } \\
0 \text { otherwise }\end{array}$ & $\begin{array}{l}\bullet \text { Weekdays: } \\
1 \text { [7:00-7:30, 16:00-16:30, } \\
\text { 18:00-18:15, 19:45-20:15, } \\
\text { 22-22:15], } 0 \text { otherwise } \\
\text { - Saturday: } \\
\text { 1 [8:45-9:15, 11:45-12:15, } \\
\text { 15:00-15:15, 18:00-18:15, } \\
\text { 19:00-20, 22:00-22:15], } \\
0 \text { otherwise } \\
\text { - Sunday and holidays: } \\
1 \text { [8:45-9:15, 11:45-12:15, } \\
\text { 15:00-15:15, 18:00-18:15, } \\
\text { 19:00-20, 22:00-22:15], } \\
0 \text { otherwise }\end{array}$ \\
\hline Library & $\begin{array}{l}\text { - Weekdays: } \\
0.5 \text { [6:30-8, 15:00-17:00, } \\
\text { 22:00-23:00], 0.75 [17:00- } \\
\text { 22:00], } 0 \text { otherwise } \\
\text { - Saturday: } \\
0.5 \text { [8:00-10:00, 15:00-17:00], } \\
0.25[10: 00-15: 00,23: 00- \\
24: 00], 0.75[17: 00-23: 00], \\
0 \text { otherwise } \\
\text { - Sunday and holidays: } \\
0.5 \text { [8:00-10:00,15:00-17:00], } \\
0.25[10: 00-15: 00,23: 00- \\
24: 00], 0.75[17: 00-23: 00], \\
0 \text { otherwise }\end{array}$ & $\begin{array}{l}\bullet \text { Weekdays: } \\
0.5 \text { [6:30-8:00, 15:00-17:00, } \\
22: 00-23: 00], \\
\text { 1.0 [17:00-22:00], } 0 \text { otherwise } \\
\text { - Saturday: } \\
0.5 \text { [8:00-10:00, 15:00-17:00], } \\
0.25[10: 00-15: 00,23: 00- \\
24: 00], 1.0[17: 00-23: 00], \\
0 \text { otherwise } \\
\text { - Sunday and holidays: } \\
0.5 \text { [8:00-10:00, 15:00-17:00], } \\
0.25 \text { [10:00-15:00, 23:00- } \\
24: 00], 1.0[17: 00-23: 00], \\
0 \text { otherwise }\end{array}$ & - \\
\hline Living room & $\begin{array}{l}\text { - Weekdays: } \\
0 \text { [8:00-15:00], } \\
0.5 \text { [15:00-24:00], } \\
1 \text { otherwise } \\
\text { - Saturday: } 1 \\
\text { - Sunday and holidays: } 1\end{array}$ & $\begin{array}{l}\bullet \text { Weekdays: } \\
0.5 \text { [6:30-8:00, 15:00-17:00, } \\
\text { 22:00-23:00], 1.0 [17:00- } \\
\text { 22:00], } 0 \text { otherwise } \\
\text { - Saturday: } \\
0.5 \text { [8:00-10:00, 15:00-17:00], } \\
0.25[10: 00-15: 00,23: 00- \\
24: 00], 1.0[17: 00-23: 00], \\
0 \text { otherwise } \\
\text { - Sunday and holidays: } \\
0.5 \text { [8:00-10:00, 15:00-17:00], } \\
0.25 \text { [10:00-15:00, 23:00- } \\
24: 00], 1.0[17: 00-23: 00], \\
0 \text { otherwise }\end{array}$ & $\begin{array}{l}\bullet \text { Weekdays: } \\
0.5 \text { [6:30-8:00, 15:00-17:00, } \\
\text { 22:00-23:00], 1.0 [17:00- } \\
\text { 22:00], 0.25 otherwise } \\
\text { - Saturdays: } \\
0.5 \text { [8:00-10:00, 17:00-19:00], } \\
\text { 1.0 [19:00-23:00], 0.25 } \\
\text { otherwise } \\
\text { - Sunday and holidays: } \\
0.5 \text { [8:00-10:00, 17:00-19:00], } \\
1.0 \text { [19:00-23:00], } \\
0.25 \text { otherwise }\end{array}$ \\
\hline
\end{tabular}


Table A1. Cont.

\begin{tabular}{clll}
\hline Name & \multicolumn{1}{c}{ Occupants } & \multicolumn{1}{c}{ Lights } & \multicolumn{1}{c}{ Equipment } \\
\hline \multirow{5}{*}{ Sauna } & $\bullet$ Weekdays: 0 & $\bullet$ Weekdays: 0 & \\
& $\bullet$ Saturday: & $\bullet$ Saturday: & \\
& $1.0[17: 30-18: 00]$, & $1.0[17: 30-18: 00]$, & \\
& $0.4[18: 00-19: 30]$, & $0.4[18: 00-19: 30], 0$ otherwise & \\
& 0 otherwise & $\bullet$ Sunday and holidays: 0 & \\
& $\bullet$ Sunday and holidays: 0 & & $\bullet$ Weekdays: 1 \\
\multirow{4}{*}{ Utility room } & - & - & $\bullet$ Saturday: 1 \\
& & & $\bullet$ Sunday and holidays: 1 \\
\hline
\end{tabular}

(C) 2013 by the authors; licensee MDPI, Basel, Switzerland. This article is an open access article distributed under the terms and conditions of the Creative Commons Attribution license (http://creativecommons.org/licenses/by/3.0/). 